\title{
Use of transgenic seeds in Brazilian agriculture and concentration of agricultural production to large agribusinesses
}

C.D. Marinho ${ }^{1}$, F.J.O. Martins ${ }^{2}$, A.T. Amaral Júnior ${ }^{1}$, L.S.A. Gonçalves ${ }^{1}$, S.C.S. Amaral ${ }^{3}$ and M.P. de Mello ${ }^{3}$

${ }^{1}$ Universidade Estadual do Norte Fluminense Darcy Ribeiro, Campos dos Goytacazes, RJ, Brasil

${ }^{2}$ Universidade Federal de Viçosa, Viçosa, MG, Brasil

${ }^{3}$ Universidade Federal Fluminense, Niterói, RJ, Brasil

Corresponding author: C.D. Marinho

E-mail: caillet.marinho@yahoo.com.br

Genet. Mol. Res. 11 (3): 1861-1880 (2012)

Received August 1, 2011

Accepted January 16, 2012

Published July 19, 2012

DOI http://dx.doi.org/10.4238/2012.July.19.6

\begin{abstract}
We identified the commercial releases of genetically modified organisms (GMOs) in Brazil, their characteristics, the types of genetic transformation used, and the companies responsible for the development of these GMOs, classifying them into two categories: private companies, subdivided into multinational and national, and public institutions. The data came from the data bank of the national registration of cultivars and the service of national protection of cultivars of the Ministry of Agriculture, Fishing and Supply (MAPA). This survey was carried out from 1998 to February 12, 2011. Until this date, 27 GMOs had been approved, including five for soybean, 15 for maize and seven for cotton cultivars. These GMOs have been used for the development of 766 cultivars, of which, 305 are soybean, 445 are maize, and 13 are cotton cultivars. The Monsato Company controls $73.2 \%$ of the transgenic cultivars certified by the MAPA; a partnership between Dow AgroSciences and DuPont accounts for $21.4 \%$, and Syngenta controls $4.96 \%$. Seed supply by these companies is almost a monopoly
\end{abstract}


supported by law, giving no choice for producers and leading to the fast replacement of conventional cultivars by transgenic cultivars, which are expensive and exclude small producers from the market, since seeds cannot be kept for later use. This situation concentrates production in the hands of a few large national agribusiness entrepreneurs.

Key words: Genetically modified organisms; Agribusiness; Private companies; Public organization

\section{INTRODUCTION}

In 2009, about 14 million farmers in 25 countries occupied 134 million hectares with genetically modified crops. According to Brookes and Barfoot (2010), since 1996, the use of genetically modified organisms (GMOs) has contributed to reducing the emission of pollutants by agriculture and boosted economic gains of producers worldwide. World gains reached US\$52 billion in 13 years. Half of this amount results from increased yield and the other half, from reduced production costs. According to these authors, in the same period, the use of transgenic products allowed an additional production of 74 and 80 million tons for the crops of soybean and maize, respectively.

Considering the area planted with crops of soybean, cotton and maize in the world, about 77, 49 and 26\%, respectively, were cultivated with GMOs (Mechlem, 2010). Among the 25 countries that produce GMOs, Brazil has the second largest cultivated area, with 21.4 million hectares, surpassed only by the USA, with 64 million hectares (Tollefson, 2010). This position was reached in 2009, when Brazil presented an increase of $35.40 \%$ in areas planted with biotech crops, thus achieving the highest rate of adoption among the countries that cultivate transgenic organisms (James, 2009). Following the same trend, in 2010, Brazil cultivated $70.6 \%$ of the 16.5 million hectares of soybean with genetically modified cultivars; $35 \%$ of the 4.3 million hectares of maize, and $15.7 \%$ of the total cotton, occupying 131,100 hectares (CONAB, 2010; Céleres, 2010, 2011). According to James (2009), the benefits of these crops in Brazil for the period between 2003 and 2008 reached US\$2.8 billion, and in 2008 alone, US\$0.7 billion.

The intrinsic characteristics of the transgenic products approved for sale in Brazil were tolerance to herbicide and/or resistance to pests. It must be highlighted that, in 2009, $62 \%$ of the transgenic crops planted in the world were tolerant to herbicides, $15 \%$ were resistant to insects, and 21\% combined both characteristics (Mechlem, 2010). In 2010, the all transgenic soybean crops were tolerant to herbicide; $87.5 \%$ of the transgenic maize crops were resistant to insects; $7.2 \%$ were tolerant to herbicides, and $5.3 \%$ presented both characteristics. Of the transgenic cotton crops, $42.6 \%$ were resistant to insects; $36.8 \%$ were tolerant to herbicides and $21.6 \%$ were resistant to both insects and herbicides (Céleres, 2010).

In such context, an intense and fast adoption of GMOs by producers can be observed, which reveals considerable economic gains. Thus, small and medium farmers are concerned with the sudden increased use of GMOs in commodity markets, in which multinational companies dominate. Biotechnological research, mainly those based on genetic engineering, are expensive and slow, which makes them available only to large companies, with advanced technology (Araújo, 2010; Potrykus, 2010). Since multinational companies dominate the mar- 
ket, make advances in research and develop new technologies, they will obviously occupy the largest share of the Brazilian market, thus reducing opportunities for national companies.

Therefore, there is an urgent need for a better understanding of this issue and its relation to farmers, the market and legislation. Some questions arise in the Brazilian agricultural scenario: i) what are the main characteristics of these cultivars? ii) which companies are responsible for the development and recommendation of transgenic cultivars in Brazil? iii) which sector presents the best performance in this field: the private or public sector? iv) what are the laws that protect GMOs? It is also important to ask: what is going to happen to family farmers that grow relevant species for the Brazilian diet? These questions are important for understanding and increasing knowledge about the breeding of transgenic cultivars and market dynamics.

Therefore, the present research aimed to identify the commercial releases of GMOs that currently exist in Brazil, the characteristics they have acquired, the events of genetic transformation used and the companies responsible for the development of these GMOs, classifying them into two categories: private companies, subdivided into multinational and national, and public organizations. Furthermore, it aimed to investigate the laws that govern the activities related to these organisms and learn more about intellectual property related to this field.

\section{METHODOLOGY}

The data used in this study were provided by the data bank of the Registro Nacional de Cultivars (National Cultivar Registry - RNC) and the Serviço Nacional de Proteção de Cultivares (National Cultivar Protection Service - SNPC), called CultivarWeb, made available in real-time on the website of the Ministry of Agriculture, Livestock and Supply (Ministério da Agricultura, Pecuária e Abastecimento - MAPA), http://www.agricultura.gov.br/. This survey was carried out from 1998 to February 12, 2011.

The survey gathered registrations and protections, according to the type of institution that requested them: private institution (later subdivided into transnational and national) and public institution. The information was tabulated and analyzed by the Microsoft Office Excel 2007 software system and the data were presented through descriptive statistics.

For the selection of the species included in this study, the commercial approvals existing in Brazil, soybean, maize and cotton, granted by the Conselho Técnico Nacional de Biossegurança (National Technical Council on Biosecurity - CTNBio), were considered. All the technical information about the commercial decisions and their events was based on the technical recommendations of that council.

\section{RESULTS AND DISCUSSION}

\section{Legislation}

In March 2005, the Biosafety Law (Law No. 11.105/05) was modified to establish safety rules and mechanisms for monitoring activities that involve GMOs and their derivatives. It also gives the CTNBio the authority to control the activities related to GMOs. According to this law, MAPA is in charge of registering and monitoring the commercial release 
of GMOs and their derivatives for animal use, in agriculture, livestock raising, agroindustry, and related areas, according to the technical recommendations of the CTNBio (Brazil, 2005).

Then, it is observed that, after an evaluation by CTNBio and a technical recommendation for the release of a certain GMO, MAPA is in charge of registering the cultivars already approved and monitoring the use of these materials. For such, MAPA coordinates the SNPC and the RNC, which is in charge of receiving the requests for protection and registration of new cultivars, including those genetically modified.

Cultivar protection is governed by Law 9.456/97 and Decree No. 2.366/97. This law basically grants a certificate that recognizes the intellectual property of a new plant variety resulting from the study of plant breeders, aiming to protect scientific knowledge, allowing individuals and organizations that carry out plant breeding to receive royalties for the use of new varieties marketed, to refund them for the investments made, encouraging them to continue the research process (Teramoto and Teixeira, 2008; Marinho et al., 2011). Therefore, the SNPC is in charge of evaluating the requests and ensuring the intellectual property rights of the producers of new phylogenetic combinations, in the form of distinct, homogenous and stable cultivars (Carvalho et al., 2009).

The RNC is governed by the Law of Seeds No. 10.711/03, which authorizes the production, processing and sale of seeds and seedlings of a cultivar throughout the country, establishing mechanisms to record and organize detailed information about the traits of the cultivars registered (Carvalho et al., 2009).

Cultivar protection is usually confused with cultivar registration, but there is a clear distinction between the two procedures. The protection, granted by the SNPC, guarantees that producers will enjoy the property rights of the cultivar developed and receive royalties for the commercialization of the material protected. Registration, on the other hand, is granted by means of the record of the cultivar in the RNC, which is a mandatory request for the production, processing and commercialization of seeds and seedlings of any cultivar, not only for the protected cultivars. Therefore, protection establishes the property rights of cultivars, while registration enables cultivars to be marketed (Teramoto and Teixeira, 2008).

Another code applied to this study is Law No. 9.279/96 (Industrial Property Law), which grants patent rights to an invention that meets the following criteria: novelty, invention activity and industrial application. This law created an exception to the prohibition on the patenting of living beings. The patent grants to its owner the right to prevent third parties from making, using, offering for sale, selling or importing, without consent, the process or product directly achieved by the patented process. Therefore, the process of insertion of a gene or genetically modified material in a plant results in products and seeds and, in this case, it is governed by the norms of Industrial Property, which grants to patent owners the right to receive royalties for their invention.

In both cases, either patent or protection of cultivars, the right to receive royalties is granted to owners. This licensing fee is established by the market, according to consumers' acceptance of the strategies of companies, without any participation from the government or farmers, since the law does not determine maximum levels for the licensing fee.

There are some significant differences between the Law of Industrial Property (LPI) and the Law of Cultivar Protection (LPC). Patents are valid for 20 years from the date of the deposit of patent request. The certificate of protection, on the other hand, is in force from the date when the Temporary Certificate of Protection is granted, and lasts 15 years, except for 
vines, fruit trees, forest trees, and ornamental trees, including in each case, their rootstock, for which the duration is 18 years. After the validity of property rights, the invented cultivar becomes public domain and no right will affect its free use.

Another important difference is that the LPC, in conflict with the LPI, guarantees the "rights of farmers", ensuring that they can reserve part of their harvest, within their properties, for future sowing without the need for previous authorization or any payment to those who developed the seeds. In other words, farmers can keep and reproduce their seeds without having to pay for a new purchase of seeds for cultivation in the next sowing season. The LPC also allows small rural producers to multiply seeds for donation or exchange, exclusively with other small rural producers, as part of programs for funding or supporting small rural producers, conducted by public organs or NGOs authorized by government. The law also provides for a "breeders' exemption", admitting the free use of the protected cultivar for research, as a source of variation. This means that, based on improved seeds, farmers can develop other seed variations, continuing the breeding process (Brasil, 1997).

Therefore, it can be observed that intellectual property of plant breeding is under the effects of the LPC, which is the only form of plant protection, including for genetically modified products. However, a gap is observed when the product of the genetic engineering process becomes patentable. In this case, genetically modified seeds are protected by the LPI. It is possible to see that GMOs can be protected twice (although Brazil is a supporter of the 1978 UPOV Convention, which prohibits such practice), since they can be patented because they are the fruit of a biotechnological process, and protected, when new cultivars are developed from a previously patented procedure.

Therefore, this legislation has been questioned. Patents are very strict in relation to the rights of the owners and do not allow any inventions to be released without the consent of the inventors. However, the Law of Protection guarantees the rights of farmers and breeders. Thus, if a cultivar were both patented and protected, the Law of Protection would break the rigidity of the patent, since producers could keep seeds for future planting seasons, which in fact does not occur, because one of the main clauses in the contracts for the release of patented technology is prohibiting farmers to keep seeds to be used in the following harvest.

\section{GMOs approved for sale}

Table 1 gathers information about the genetic transformation events released until now, the genes inserted, traits achieved and companies responsible for the patents.

In Brazil, CTNBio, by the time of this study, had approved 27 GMOs, five for soybean, 15 for maize and seven for cotton. The first approval occurred in 1998, with the soybean "Roundup Ready" from Monsanto, whose release was later suspended in Brazil and allowed again in 2005 . Since then, one genetically modified cotton was released in 2005 , three releases of maize were approved in 2007, and five other releases in 2008, three of maize and two of cotton. In 2009, nine releases were approved, one for soybean, five for maize and three for cotton. In 2010, eight new GMOs were approved, three for soybean, four for maize and one for cotton. It is undeniable that there has been a fast increase in GMO releases over the last three years. Thus, in 2008, 2009 and 2010 alone, 22 GMO releases were approved by CTNBio, of a total of 27 releases since 1998 (Table 1). 


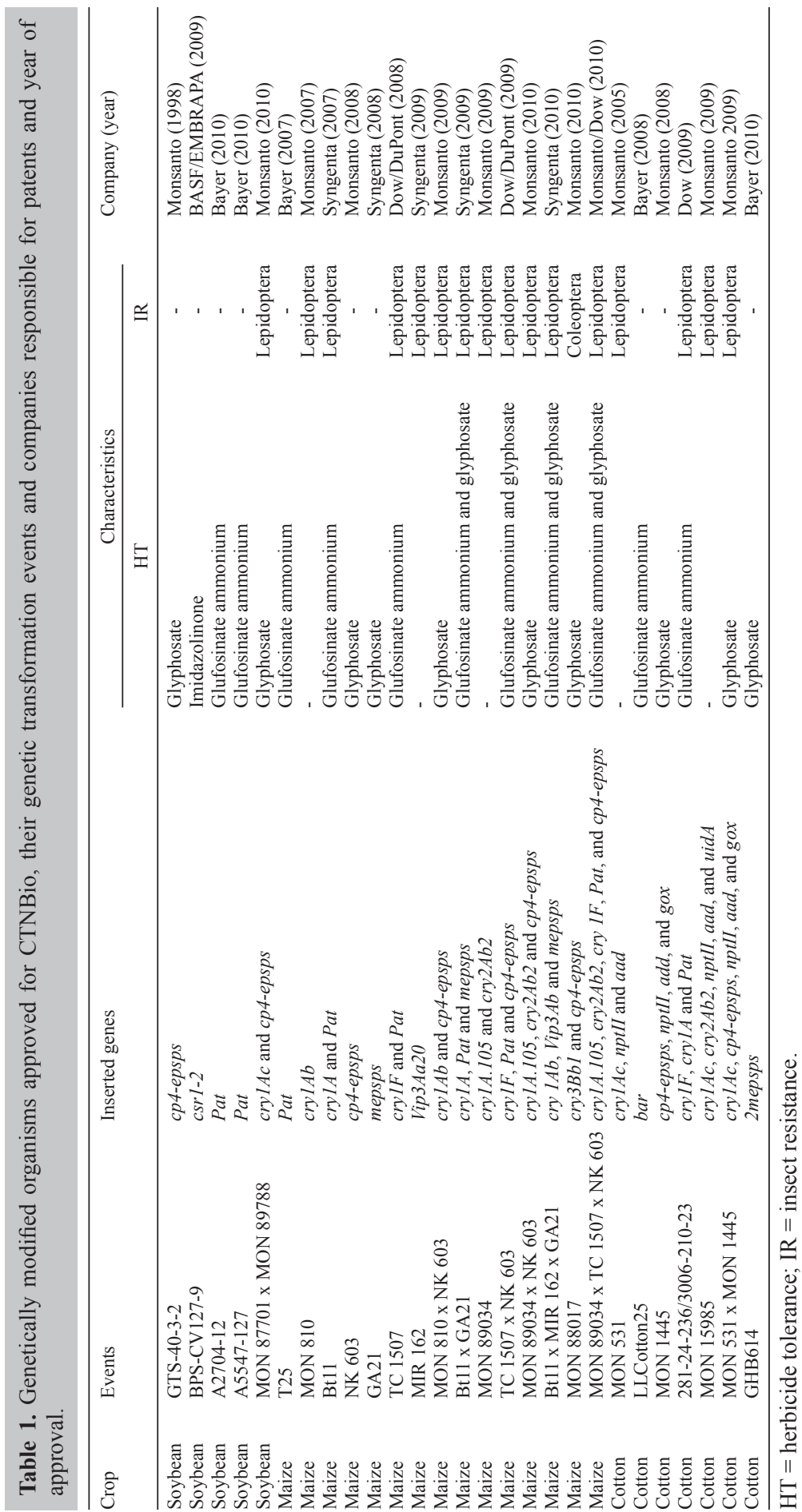


It is important to stress that only one GMO was developed by a Brazilian institution, namely, the soybean Cultivance (event BPS-CV127-9) (Table 1), approved in 2010. It was the result of a partnership between the Embrapa and Basf, which means that Brazil depends on transgenic seeds produced by private transnational companies. Table 1 demonstrates that the other GMOs were developed by multinational companies, namely: Monsanto (12), Monsanto in partnership with Dow AgroSciences (1), Syngenta (5), Bayer (5), DuPont and Dow AgroSciences (2), and Dow AgroSciences (1). Therefore, six multinational companies alone dominate this biotechnological segment. Monsanto alone holds $44.44 \%$ of the patents, followed by Syngenta and Bayer, each holding $18.52 \%$. A simple analysis reveals that these three companies hold $81.5 \%$ of the patents of the GMOs in Brazil.

\section{Genetically modified (GM) soybean}

Soybean has five GMOs approved. The first release occurred for the event GTS-403-2, which generated the soybean "Roundup Ready", from Monsanto, to which the cp4-epsps gene, from the soil bacterium Agrobacterium tumefaciens was inserted, thus conveying tolerance to the herbicide glyphosate, the main ingredient of the herbicide "Roundup Ready", owned by Monsanto (CTNBio, 2011).

Then, in 2009, BPS-CV127-9 originated the Soybean Cultivance, from Basf in partnership with Embrapa, in which the csr1-2 gene from Arabidopsis thaliana was introduced, imparting tolerance to imidazolinone herbicides (CTNBio, 2011). Shortly thereafter, the soybean "Liberty Link" (soybean LL) was created by Bayer, from the event "A2704-12", which resulted from the insertion of the Pat gene, a modified version of the gene isolated from the natural soil bacterium Streptomyces viridochromogenes, thus imparting tolerance to glufosinate ammonium (CTNBio, 2011). "A5547-127" was another release from Bayer, also called soybean "Liberty Link", with the same traits of "A2704-12", but containing only one copy of the Pat gene inserted into the plant genome, instead of two copies, as performed in the event "A2704-12" (CTNBio, 2011).

The soybean "MON 87701 x MON 89788" was derived from crossing by classic genetic breeding techniques. In this case, parents of genetically modified soybean were used. MON 87701 expresses resistance to pests, and MON 89788, tolerance to glyphosate. The event MON 87701 has the gene crylAc, from the Bacillus thuringiensis, and the event MON 89788 contains the cp4-epsps gene, from Agrobacterium sp. The crylAc gene expresses the protein Cry1Ac, which presents insecticidal activity, thus guaranteeing resistance to Lepidoptera, pests of tropical and subtropical regions, mainly the attack from Anticarsia gemmatalis, caterpillar of soybean, and Pseudoplusia includens, false semi-looper, as primary targets, and Crocidosema aporema, bean shoot borer, and Rachiplusia $n u$, also known as semi-looper, as secondary targets, which are also significant in crops of South America. The cp4-epsps gene imparts tolerance to glyphosate. The result of this event was the achievement of soybean resistance to pests and tolerance to the herbicide glyphosate (CTNBio, 2011).

\section{GM maize}

The first approval for maize occurred in 2007, "Liberty Link", from Bayer, event "T25", with the introduction of the Pat gene, the same as the soybean "Liberty Link", modi- 
fied from the natural soil bacterium $S$. viridochromogenes, which imparts tolerance to the herbicide glufosinate ammonium (CTNBio, 2011). In the same year, the Monsanto event "MON 810 " was approved and originated the maize "Guardian", by the insertion of the crylAb gene, from B. thuringiensis subsp kurstaki, which codifies the protein Cry1 Ab, which confers a toxic effect to pests of the order Lepidoptera, which include the army worm larvae (Spodoptera frugiperda), corn earworm (Helicoverpa zea) and sugarcane borer (Diatrea saccharalis) (CTNBio, 2011). Shortly thereafter, the maize "Bt11" was created by Syngenta, containing the cry $1 A$ and Pat genes, added by the transformation event "Bt11". This maize expresses the crylA gene (b), which is the fusion of the crylA and Pat genes, from the bacteria B. thuringiensis var. kurstaki and $S$. viridochromogenes, respectively. Thus, the plant presents traits of resistance to pests and tolerance to the herbicide glufosinate ammonium. The following pests were affected: army worm larvae (S. frugiperda), corn earworm (H. zea) and cut worm (Agrotis ipsilon) (CTNBio, 2011).

In 2008, three other requests were granted, starting with the maize "Roundup Ready 2", from Monsanto, "NK 603" event, with the insertion of the cp4-epsps gene, from A. tumefaciens, giving tolerance to the herbicide glyphosate (CTNBio, 2011). Shortly thereafter, two other approvals were granted; the first, maize "GA21" from Syngenta, tolerant to the herbicide glyphosate, developed by the event "GA21", with the insertion of the mepsps gene (modified from the conventional epsps gene of maize) (CTNBio, 2011). The second was the maize "Herculex", developed through a partnership between Dow AgroSciences and DuPont. The transformation event used was called "TC 1507", which introduced the crylF and Pat genes, the first from the bacterium B. thuringiensis var. aizawai, and the second, from S. viridochromogenes. The $c r y l F$ gene imparts resistance to the following pests of the order Lepidoptera: army worm larvae (Spodoptera frugiperda), corn earworm (H. zea) and sugarcane borer $(D$. saccharalis); on the other hand, the Pat gene conveys tolerance to the herbicide glufosinate ammonium (CTNBio, 2011).

There were five releases in 2009 for maize, the first one was the maize "MIR 162", achieved by the event "MIR 162", with consequent inclusion of the Vip3Aa20 gene, from B. thuringiensis, which guarantees resistance to army worm larvae (S. frugiperda), corn earworm (H. zea) and sugarcane borer (D. saccharalis) (CTNBio, 2011). Monsanto also achieved the release of a "pyramidal" maize, "MON 810 x NK 603", from the crossing between NK603 and MON 810 by classical genetic breeding, which resulted in maize tolerant to glyphosate and resistant to pests of the order Lepidoptera (CTNBio, 2011). Another "pyramidal" maize was approved, from Syngenta, namely, "Bt11 x GA21", achieved by classical genetic breeding of the crossing between genetically modified lineages containing isolatedly the event "Bt11" and the event "GA21", combining the traits of their parents, namely, resistance to Lepidoptera, and tolerance to glyphosate and glufosinate ammonium (CTNBio, 2011).

Then, the maize "MON 89034" also received a license. It contained the crylA.105 and cry $2 A b 2$ genes, from the bacterium $B$. thuringiensis, conferring resistance to army worm larvae (S. frugiperda), corn earworm ( $H$. zea) and sugarcane borer (D. saccharalis), and high control of species of Ostrinia, including the European corn borer and Asian corn borer (CTNBio, 2011). The last approval in 2009 was granted to a "pyramidal" maize, received by Dow AgroSciences in partnership with DuPont, "TC 1507 x NK 603", produced from classical genetic breeding using crossing between lineages genetically modified containing the events "TC 1507" and "NK 603", also conferring tolerance to the herbicides glufosinate ammonium and glyphosate, and resistance to Lepidoptera (CTNBio, 2011). 
The first GMO approved in 2010 was the maize "MON 89034 x NK 603", resulting from the crossing of the parents of genetically modified maize resistant to insects, by classical genetic breeding, by means of the event "MON 89034", which allows tolerance to the herbicide glyphosate, and the event "NK 603", from Monsanto (CTNBio, 2011). The next one was the maize "Bt11 x MIR 162 x GA21" from Syngenta, which agglutinated the events already mentioned in a single organism (CTNBio, 2011). The maize "MON 88017" (event "88017"), from Monsanto, also received a favorable recommendation. This genotype received the cry $3 B b 1$ and $c p 4$-epsps genes. The first comes from the bacterium B. thuringiensis and the second from Agrobacterium sp. The cry $3 B b 1$ gene is responsible for resistance to larvae of pests of the genus Diabrotica, and the cp4-epsps gene imparts tolerance to glyphosate (CTNBio, 2011). Finally, another "pyramidal" procedure originated the maize "MON 89034 x TC 1507 x NK 603", from Monsanto and Dow AgroSciences, absorbing the traits of tolerance to glyphosate and glufosinate ammonium and resistance to Lepidoptera (CTNBio, 2011).

\section{GM cotton}

The first transgenic cotton was "Bollgard", from Monsanto (event "MON 531"), released in 2005. This genotype holds the crylAc gene, which comes from the bacterium $B$. thuringiensis var. kurstaki and imparts resistance to insects. The GMO mentioned resists the main pests of the order Lepidoptera, which affect cotton cultivation in Brazil, including the curuquerê-do-cotton (Alabama argillacea), pink bollworm (Pectinophora gossypiella) and tobacco budworm (Heliothis virescens) (CTNBio, 2011).

In 2008, Bayer developed the cotton "Liberty Link" (event "LLCotton25"), with tolerance to glufosinate ammonium, conferred by the gene bar, from Streptomyces hygroscopicus (CTNBio, 2011). In the same year, Monsanto developed the cotton "Roundup Ready" (event "MON 1445"), tolerant to glyphosate, a trait attributed to the cp4-epsps gene, from the soil bacterium Agrobacterium sp (CTNBio, 2011).

In 2009, the cotton "Widestrike" was achieved by Dow AgroSciences (event "281-24236/3006-210-23"), whose genotype holds the crylF, crylA and Pat genes. The two first genes, achieved from $B$. thuringiensis var. aizawai strain PS811 and from $B$. thuringiensis var. kurstaki strain HD73, confer resistance to the following pests: $H$. virescens, $H$. zea, S. frugiperda, $A$. argillacea, P. gossypiella, Spodoptera exigua, Spodoptera eridania, P. includens, and Trichoplusia ni. The Pat gene is a synthetic version derived from the Pat gene from S. viridochromogenes, which allows the expression of tolerance to glufosinate ammonium (CTNBio, 2011).

In 2009, Monsanto also launched two genotypes of genetically modified cotton plants: "Bollgard II" (event "MON 15985") and "MON 531 x MON 1445" (events "MON 531 x MON 1445"). Bollgard II is resistant to pests, including curuquerê (A. argillacea), tobacco budworm (H. virescens), pink bollworm ( $P$. gossypiella) and army worm larvae of maize ( $S$. frugiperda). These types of resistance were enabled by the insertion of the crylAc and cry $2 \mathrm{Ab} 2$ genes, from the bacterium B. thuringiensis var. kurstaki (CTNBio, 2011). On the other hand, in "MON $531 \times$ MON 1445", there is a combination of events of resistance to pests and tolerance to the herbicide glyphosate (CTNBio, 2011).

Later, in 2010, Bayer produced another genotype of genetically modified cotton plant, called "GlyTol ${ }^{\mathbb{B}}$ " (event "GHB614"), which holds the 2mepsps gene (modification of the epsps gene of maize) inserted in the genome of cotton plants, imparting tolerance to the herbicide glyphosate (CTNBio, 2011). 


\section{Genetically modified cultivars versus transformation event used}

When CTNBio grants commercial approval to a GMO, it also releases all the progenies from the transformation event in question, derived from crossings between non-transgenic lineages and populations and lineages involved in the event, as well as the byproducts achieved. However, the Ministry of Agriculture, Livestock Raising and Supply (MAPA) is in charge of registering and monitoring all the genetically modified cultivars from the transformation event released by the CTNBio, allowing them to be produced and marketed.

These procedures produce the cultivars made available for planting in Brazil. Both the conventional and genetically modified products go through a process of evaluation and recommendation by MAPA, and can also be protected, safeguarding the intellectual rights of breeders, and ensuring permission for commercial exploitation (royalties) for a certain period of time (Carvalho et al., 2009). Therefore, all the cultivars that have been registered are recorded in the RNC and all the cultivars protected are recorded in the SNPC.

Three plant species were released for the commercialization of genetically modified cultivars in Brazil (Glycine max, Zea mays and Gossypium hirsutum). There are 293 soybean cultivars recorded and 180 protected. Of these, only 12 were exclusively protected, which demonstrates that the current total number of genetically modified soybean genotypes is 305 .

All the 448 GM maize cultivars were only registered. On the other hand, GM cotton holds 10 registration records and 11 protections, of which only three cultivars were exclusively protected, revealing that there are 13 GM cotton cultivars in the country.

Thus, Table 2 separates the existing GM cultivars, according to the genetic transformation event used for obtaining them. It is observed, therefore, that nine different events were used for maize to create the 448 cultivars registered. Of these, $54.91 \%$ have Monsanto technology; 36.61\%, Dow AgroSciences in partnership with DuPont, and, 8.48\%, Syngenta. Therefore, all maize cultivars registered at MAPA come from technology that belongs to only four multinational companies: Monsanto, Dow AgroSciences, DuPont, and Syngenta.

Table 2. Number of existing genetically modified organisms of maize, cotton and soybeans registered and/ or protected in the Ministry of Agriculture, Livestock and Supply (Ministério da Agricultura, Pecuária e Abastecimento - MAPA), classified according to the genetic transformation event and the companies responsible for the events used.

\begin{tabular}{|c|c|c|c|c|c|}
\hline & Event & Number of cultivar & Company & Total/company & $\%$ \\
\hline \multirow[t]{10}{*}{ Maize } & MON 810 (Guardian) & 106 & Monsanto & 246 & 54.91 \\
\hline & NK 603 (Roundup Ready 2) & 77 & Monsanto & & \\
\hline & MON $810 \times$ NK 603 & 36 & Monsanto & & \\
\hline & MON 89034 & 27 & Monsanto & & \\
\hline & Bt11 & 25 & Syngenta & 38 & 8.48 \\
\hline & MIR 162 & 8 & Syngenta & & \\
\hline & Bt11 x GA21 & 5 & Syngenta & & \\
\hline & TC 1507 (Herculex) & 120 & Dow/DuPont & 164 & 36.61 \\
\hline & TC 1507 x NK 603 & 44 & Dow/DuPont & & \\
\hline & Total & & & 448 & 100.00 \\
\hline \multirow[t]{6}{*}{ Cotton } & MON 1445 (Roudup Ready) & 4 & Monsanto & 10 & 76.92 \\
\hline & MON 531 (Bollgard) & 4 & Monsanto & & \\
\hline & MON $531 \times$ MON 1445 & 2 & Monsanto & & \\
\hline & LLCotton25 (LibertyLink) & 2 & Bayer & 2 & 15.38 \\
\hline & 281-24-236/3006-210-23 (WideStrike) & 1 & Dow AgroSciences & 1 & 7.69 \\
\hline & Total & & & 13 & 100.00 \\
\hline \multirow[t]{2}{*}{ Soybean } & GTS-40-3-2 (Roudup Ready) & 305 & Monsanto & 305 & 100.00 \\
\hline & Total & & & 305 & 100.00 \\
\hline
\end{tabular}


Table 2 also demonstrates that, for the 13 different GM cotton cultivars registered and/or protected, five genetic transformation events were used, of which 10 used technology from Monsanto, two from Bayer and one from Dow AgroSciences. Thus, all the existing GM cotton cultivars hold technology from only three transnational companies: Monsanto, Bayer and Dow AgroSciences.

It is very interesting to note that, for the forms of genetically modified soybean, all the 305 different cultivars registered and/or protected in the MAPA come from the "Roundup Ready" technology, which belongs to Monsanto (Table 2).

Table 3 presents the total number of GM cultivars, separated by the companies that hold the technologies employed. There are 766 GM cultivars with a MAPA certificate, and only five transnational companies are responsible for the technologies adopted. It is also possible to observe that Monsanto is the owner of the processes used in $73.24 \%$ of these cultivars, which demonstrates the prevalence of this company in this segment.

$\begin{aligned} & \text { Table 3. Total number of genetically modified crops by separate companies that were responsible for the } \\
& \text { technology used in obtaining these cultivars. }\end{aligned}$
\begin{tabular}{lcr}
\hline Company & Total number (maize, soybean and cotton) & $\%$ \\
\hline Monsanto & 561 & 73.24 \\
Dow/DuPont & 164 & 21.41 \\
Syngenta & 38 & 4.96 \\
Bayer & 2 & 0.26 \\
Dow AgroSciences & 1 & 0.13 \\
Total & 100 & 100.0 \\
\hline
\end{tabular}

It is important to point out that $82.81 \%$ of the existing GM maize cultivars present resistance to Lepidoptera, and in $31.47 \%$, this trait is exclusive (without combination). Tolerance to herbicides is a trait presented by $68.53 \%$, or 307 cultivars. And this trait is exclusive in only $17.19 \%$. In addition, $145(32.37 \%)$ express tolerance to glufosinate ammonium, 113 $(25.22 \%)$, to glyphosate, and $10.94 \%$, to two herbicides. In the investigation on the combination of traits from modifying events, it can be seen that $51.34 \%$ of the cultivars present both tolerance to herbicide and resistance to insects.

Resistance to Lepidoptera can be found in $53.85 \%$ of cotton cultivars, and $30.77 \%$ do not present a combination of genetic modifications. Also, $69.23 \%$ of the cultivars are tolerant to herbicides. Of these, $46.15 \%$ are tolerant to glyphosate and $23.08 \%$ to glufosinate ammonium. Finally, $23.08 \%$ of the cultivars offer the combined traits of tolerance to herbicide and resistance to insects.

Regarding soybean culture, all the cultivars present only tolerance to glyphosate. For the sum of the three crops and their 766 existing GM cultivars, 424 or $55.35 \%$ present tolerance to glyphosate, 148 or $19.32 \%$, tolerance to glufosinate ammonium, and 49 or $6.40 \%$, to the two traits combined. As a result, $81.07 \%$ or 621 cultivars are tolerant to herbicides. Consequently, the control of multinational companies over the sale of products is clear, since the herbicides are purchased together with the seeds (Munro, 2003). Besides, Monsanto is the most benefited, since glyphosate is the main active ingredient of "Roundup Ready", sales leader, which belongs to Monsanto. 


\section{Protections}

There are 180 GM soybean crops protected by MAPA, 146 (81.12\%) were developed by private institutions and only $34(18.88 \%)$, by public institutions. There are $11 \mathrm{GM}$ cotton cultivars protected, all developed by private companies. As of yet, there is no protected GM maize cultivar (Figure 1).

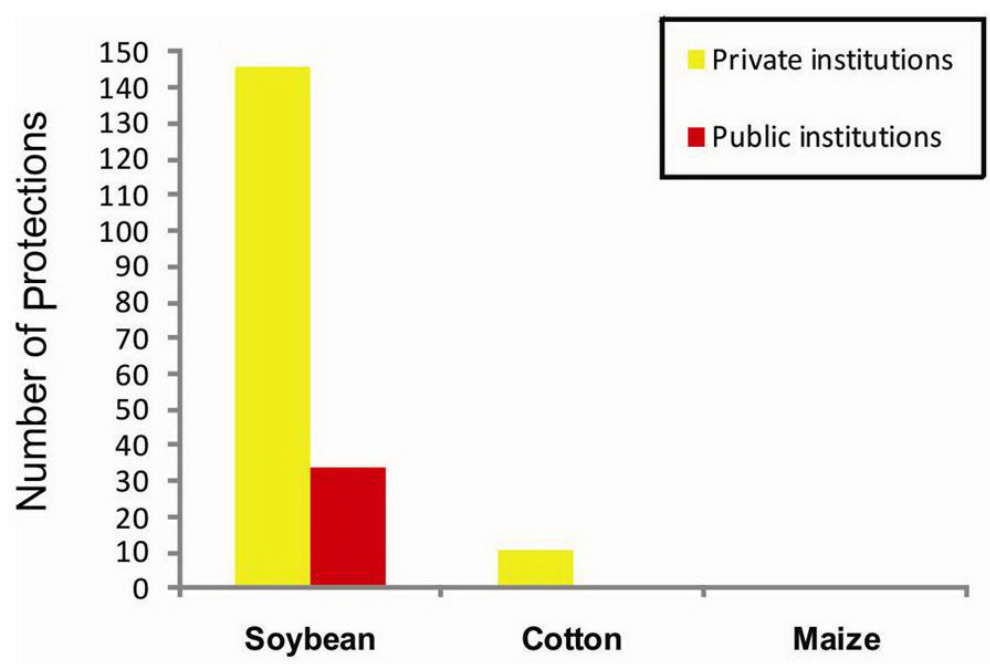

Figure 1. Number of protections for transgenic crops of soybean, cotton and maize, according to the type of holding institutions.

The number of GM cultivars produced by private institutions can still be classified into national and multinational companies, whose percentage for soybean corresponds to 18.34 and $62.78 \%$, respectively, and for cotton, 9.09 and $90.91 \%$ (Figure 2).

A

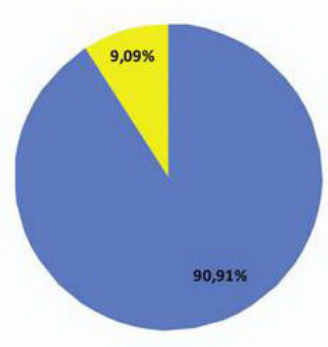

Cotton
B

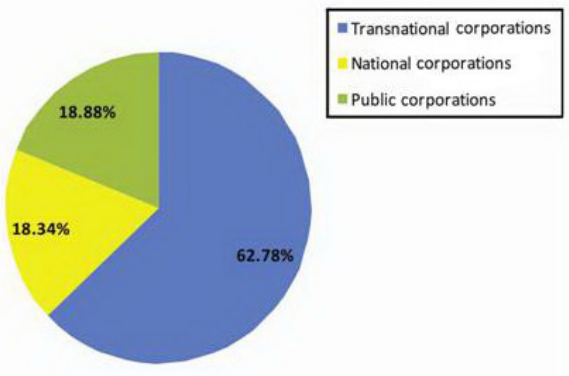

Soybean

Figure 2. A. Percentage of protections belonging to different classifications of the holding institutions for genetically modified (GM) cotton crops. B. Percentage of protections belonging to different classifications of the holding institutions for the cultivation of GM soybean. 
The public companies that maintain genetically modified soybean cultivars and their respective numbers of protection are: Agência Goiana de Desenvolvimento Rural e Fundiário - AGENCIARURAL (2); Secretaria de Agricultura Pecuária e Abastecimento do Estado de Goiás - SEAGRO (2); Empresa Brasileira de Pesquisa Agropecuária - EMBRAPA (27); EMBRAPA in partnership with Empresa de Pesquisa Agropecuária de Minas Gerais EPAMIG (1); EMBRAPA in partnership with SEAGRO (1); EMBRAPA in partnership with AGENCIARURAL (1); they represent 34 protections or $18.88 \%$.

The private national companies are: Cooperativa Central de Pesquisa Agrícola COODETEC (13); Fundação Centro de Experimentação e Pesquisa Fecotrigo - FUNDACEPFECOTRIGO (5); Tropical Melhoramento e Genética Ltda. - TMG (4); Fundação de Apoio à Pesquisa Agropecuária de Mato Grosso - Fundação MT, in partnership with Unisoja S.A. and the TMG (9); Fundação MT and Unisoybean S.A. (1), and finally, an individual, Luiz Alberto Benso (1), which correspond to 33 protections or $18.34 \%$.

The multinational companies are as follows: Anglo Netherlands Graisn B.V. (4); Associados Don Mario S.A. (11); DuPont (10); Granar S.A. (10); Monsoy (47); FT seeds S.A. (13); Nidera S.A. (9), and Syngenta Seeds Ltda. (9). It must be highlighted that Monsoy and FT seeds belong to Monsanto, and, together, they have 60 (33.33\%) protected GM soybean cultivars. There are 113 protections from these multinational companies, which represent $62.78 \%$.

Only one cotton cultivar was developed by a national company, the Instituto Matogrossense do Algodão - IMAMT, and the 10 remaining were developed by Delta \& Pine Land Technology Holding Company, which belongs to Monsanto.

Figure 3 shows the number of protected and genetically modified cultivars, developed from 1998 to 2010. It is possible to see the increased number of protections of GM soybean in recent years, even higher than the number of conventional soybean. Since 2006, the quantity of protections of transgenic soybean cultivars has been higher than the conventional. Besides the significant growth, the quantity of cultivars that are not transgenic is decreasing, thus evidencing the replacement of non-transgenic cultivars by transgenic cultivars. There is no relation that can be called linear for cotton culture, since there was no overlapping of the number of protected genetically modified cultivars and it has not been continuous over the years. In this aspect, more GM cultivars were granted protection in 2007 and 2010.

\section{Registrations}

At present, there are 448 cultivars of GM maize registered at MAPA, and all of them were developed by private multinational companies. There are 293 registered GM soybean cultivars, of which 236 (80.55\%) were produced by private companies and $57(19.45 \%)$, by public institutions. There are $10 \mathrm{GM}$ cotton registered cultivars, all of them developed by private institutions (Figure 4).

In the classification of the private companies, after subdividing them into national and multinational companies (Figure 5), it is observed that $40.96 \%$ of the GM soybean registrations belong to multinational companies and $39.59 \%$, to national companies, totaling $80.55 \%$ for private companies. Only one cotton cultivar was developed by a national company, which is $10 \%$ of the total registered cultivars. 


\section{Soybean}

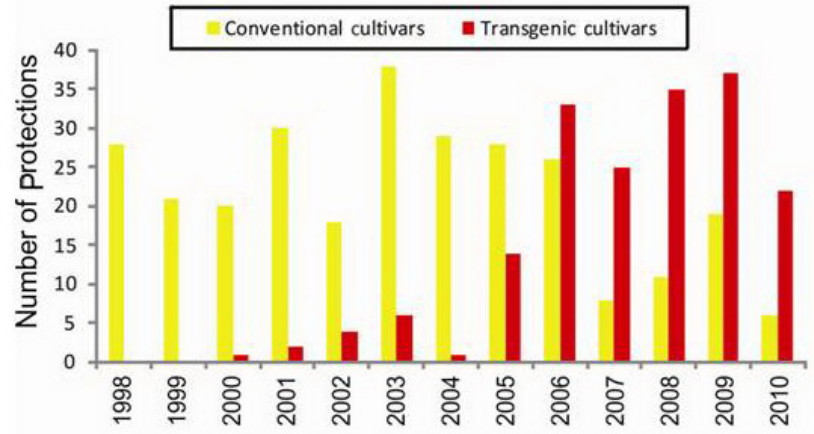

Cotton

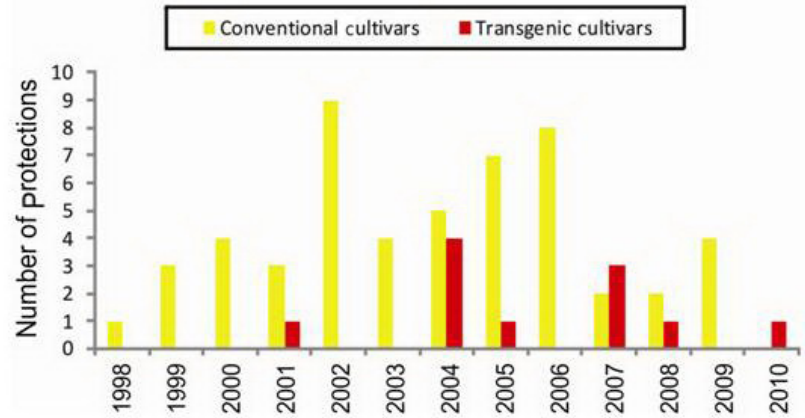

Figure 3. Number of conventional and protected transgenic cultivars from 1998 to 2010 for the crops of soybean and cotton.

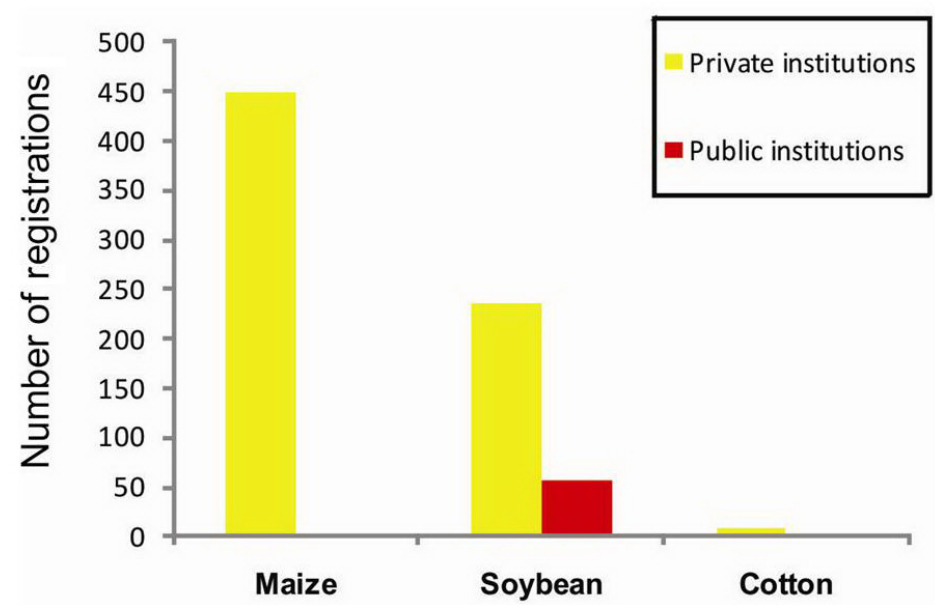

Figure 4. Number of registrations for the transgenic crops of maize, soybean and cotton, according to the type of holding institutions. 

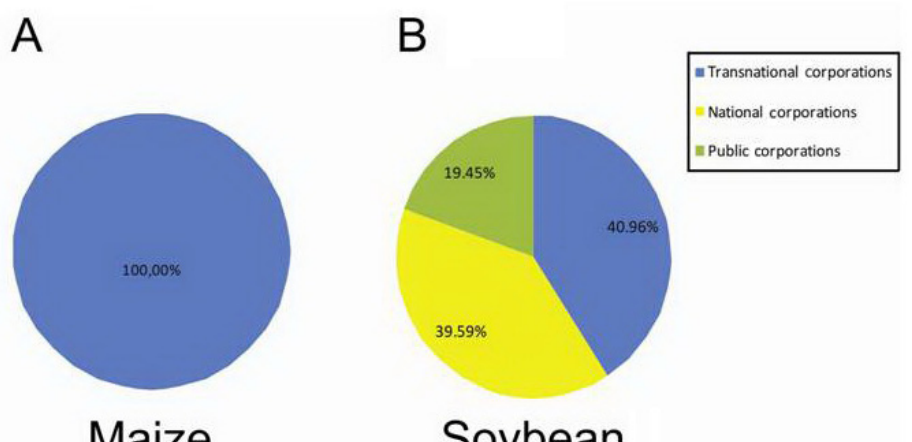

Maize

Soybean

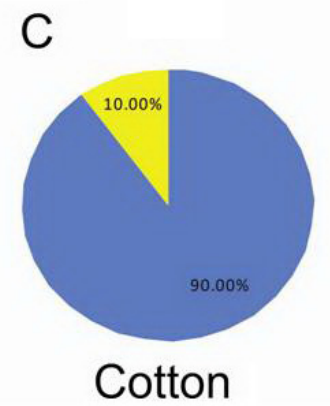

Figure 5. A. Percentage of registrations belonging to different classifications of the holding institutions for the culture of transgenic maize. B. Percentage of registrations belonging to different classifications of the holding institutions for the cultivation of transgenic soybean. C. Percentage of registrations belonging to different classifications of the holding institutions for the cultivation of transgenic cotton.

The private companies responsible for the GM maize cultivars are: DuPont (212), Monsanto (141), Dow AgroSciences (41), Agromen Tecnologia Ltda. (10), Syngenta (39), and Nidera (5). Considering that Agromen Tecnologia is a subsidiary of Dow AgroSciences, it can be concluded that only five companies are responsible for all the GM maize cultivars currently in Brazil. Besides, Syngenta holds $47.32 \%$ of these registrations of maize and Monsanto, $31.47 \%$. These two companies alone hold almost $80 \%$ of the market for this culture.

The following multinational companies deal with soybean: DuPont (18), Monsoy (54) and FT seeds (20), which belong to Monsanto, totaling 74 cultivars owned by Monsanto, Nidera (17), and Syngenta (11), totaling 120 (40.96\%). It is clear that Monsanto predominates in the market, holding $25.26 \%$ of the registrations of GM soybean cultivars.

The national private institutions responsible for the registrations of GM soybean are: BR Genética Ltda. (5); Brasmax Genética Ltda. (16); Caraíba Genética Ltda. (6); Cooperativa Central de Pesquisa Agrícola - COODETEC (33); Fundação Centro de Experimentação e Pesquisa Fecotrigo - FUNDACEP-FECOTRIGO (9); Tropical Melhoramento e Genética Ltda. - TMG (7); Fundação de Apoio à Pesquisa Agropecuária de Mato Grosso - Fundação MT in partnership with Unisoja S.A. and TMG (18); Fundação MT e Unisoja S.A. (9); Soy Tech Seeds Pesquisa em Soja Ltda. (3); Wehrtec Tecnologia Agrícola Ltda. (9), and finally, an individual, Luiz Alberto Benso (1); totaling 39.59\% or 116 registered GM soybean cultivars. COODETEC stands out, with 33 or $11.26 \%$ of the cultivars. 
The public institutions: Agência Rural de Desenvolvimento Rural e Fundiário AGENCIARURAL (3); Universidade Federal de Viçosa - UFV (5); Secretaria de Agricultura Pecuária e Abastecimento do Estado de Goiás - SEAGRO (1); Empresa Brasileira de Pesquisa Agropecuária - EMBRAPA (39); EMBRAPA and Empresa de Pesquisa Agropecuária de Minas Gerais - EPAMIG (4); EMBRAPA and AGENCIARURAL (1); EMBRAPA and SEAGRO (2); Fundação Estadual de Pesquisa Agropecuária - FEPAGRO (2); total 57 or $19.45 \%$ of the registrations. EMBRAPA is the public institution that holds the highest number of registrations for GM soybean, namely, $13.31 \%$.

Seven cotton cultivars or $70 \%$ of the registrations belong to D\&PL Brasil Ltda., an affiliate of Monsanto. Bayer has one, or 10\%. Dow AgroSciences holds 10\% and the Instituto Matogrossense do Algodão, $10 \%$; therefore, $90 \%$ of the registered GM cotton cultivars belong to transnational companies, and Monsanto alone owns $70 \%$ of these cultivars.

Figure 6 illustrates the situation of the number of registrations of GM cultivars, compared to conventional cultivars from 1998 to 2010. It demonstrates that maize presented high growth, especially considering that it was released in 2007. In 2009 and 2010, the number of GM maize cultivars surpassed the number of conventional maize cultivars, in such a way that there were 75 more transgenic cultivars in 2009, and 45 in 2010, compared to conventional cultivars. Soybean presented similar growth, but, since 2006, the number of GM cultivars has surpassed the conventional cultivars, mainly in 2009 and 2010, when the difference was more pronounced. Therefore, as with the protections, the number of registrations of transgenic soybean is increasing and surpassing the conventional. Besides, the decreasing number of non-transgenic cultivars demonstrates that genetically modified products are replacing the conventional ones. Regarding cotton, a more constant number was observed from 2005 to 2008, when the number of registered conventional cultivars was higher. However, in 2009 and 2010, the number of GM cultivars exceeded the conventional cultivars.
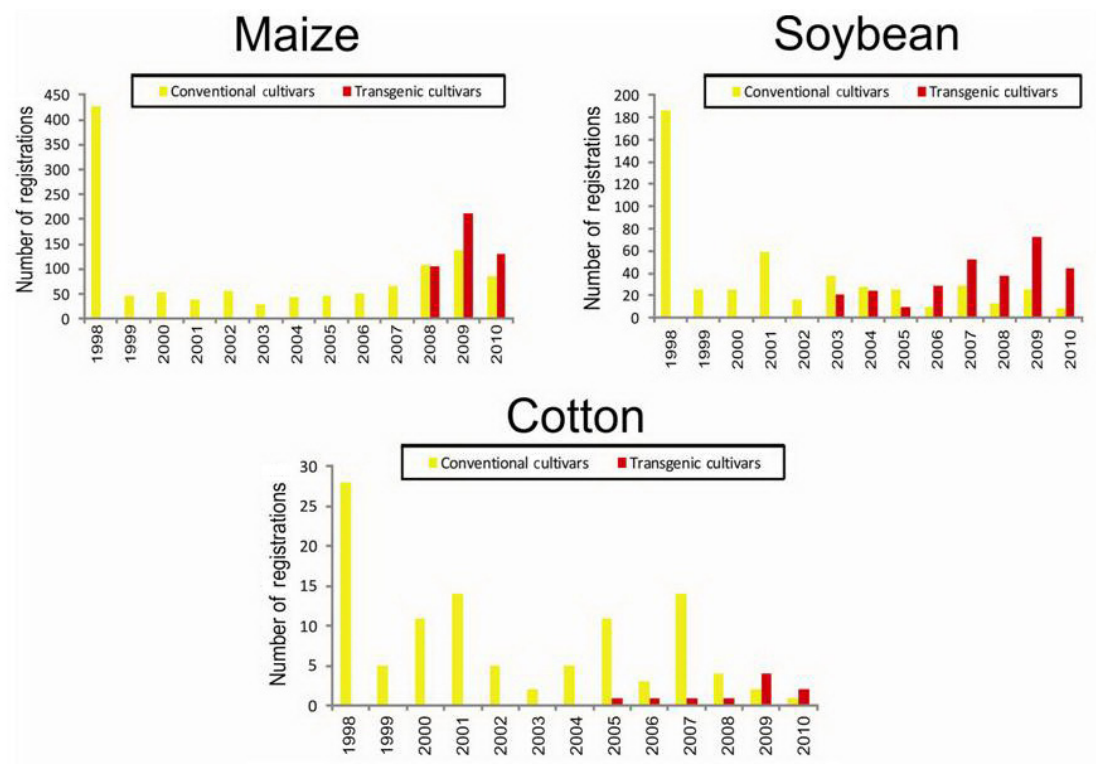

Figure 6. Number of conventional and transgenic cultivars registered from 1998 to 2010 for maize, soybean and cotton crops. 


\section{CONCLUSIONS AND PERSPECTIVES}

Today, there are 27 GMOs authorized by CTNBio for sale in Brazil, 15 maize, five soybean and seven cotton cultivars (Table 1). However, only nine, of the 15 events of maize; five of the seven events for cotton, and one event for soybean have cultivars certified by MAPA (Table 2). These events generated 766 cultivars, of which 448 are maize; 305 , soybean, and 13, cotton cultivars (Tables 2 and 3). All 448 cultivars of maize were only registered. There are 293 registrations and 180 protections for soybean. Only twelve protected cultivars were not registered as well, which results in 305 current cultivars. Therefore, $59.02 \%$ of the existing transgenic soybean cultivars are protected, which means that seeds become more expensive, since, besides the royalties paid for the patent of the biotechnological processes, by means of a direct contract signed by farmers, the seeds made available for producers will add to the value of the royalties related to cultivar protection.

Ten registrations and 11 protections were counted for cotton. Only three cultivars were exclusively protected, which resulted in the 13 existing cultivars. Therefore, there was a protection rate of $84.62 \%$, for transgenic cotton.

The study reveals that the genetic engineering market is restricted almost exclusively to private companies, since only EMBRAPA, as the national representative, has developed one event that is not, however, exclusively held by this institution, since its GMO cultivar was created in partnership with BASF. All the other GMO cultivars belong to only five multinational organizations: Monsanto (12), Monsanto and Dow AgroSciences (1), Syngenta (5), Bayer (5), DuPont and Dow AgroSciences (2), and Dow AgroSciences (1) (Table 1). Monsanto, which has $48.15 \%$ of the commercial releases, deserves special attention.

However, considering the existing transgenic cultivars certified by MAPA, and the events used to develop them, $73.24 \%$ of the technologies used belong to Monsanto. Then, there is the partnership between Dow AgroSciences and DuPont, with $21.41 \%$ of the utilizations and Syngenta, with $4.96 \%$. It can be concluded that these four multinational companies have $99.74 \%$ (if added to the $0.13 \%$ of Dow AgroSciences exclusively) of the technologies adopted to obtain the existing transgenic products authorized by MAPA. Besides, there is a large gap between Monsanto and the other companies, thus corroborating the degree of dominance of this company in the industry (Table 3 ).

In this context, Monsanto holds the lead (Table 2) for the three crops. All certified soybean cultivars were developed by the techniques patented by Monsanto, as well as $54.91 \%$ of the cultivars of maize and $76.92 \%$ of cotton. In other words, besides holding the most transformation events released for commercialization (44.15\%), this company still adopts the most technology for the development of transgenic products (73.24\%). Besides, the study demonstrates that $55.35 \%$ of all transgenic cultivars authorized by MAPA are tolerant to the herbicide glyphosate, the main component of the herbicide "Roundup Ready", from Monsanto. Considering the unavoidable associated purchase of transgenic seed and herbicide, to which the plant is tolerant, it is observed that Monsanto also dominates the supply of the herbicide employed in transgenic plantations. This situation makes it even more difficult for family farmers to acquire seeds at reasonable prices and prevents the farmer segment from producing in the transgenic market. In fact, family farmers are expected to be weakened by the increased use of transgenic seeds in the market.

Regarding the institutions responsible for the development of the cultivars certified 
by MAPA, the study verified that 180 transgenic soybean cultivars were protected, and 146, or $81.12 \%$, belong to private institutions, of which $62.78 \%$ are multinational companies and $18.34 \%$, national companie, and 34 or $18.88 \%$, public institutions (Figures 1 and 2). It is important to observe that Monsanto and its affiliates alone hold $33.33 \%$ of the protections of GM soybean, which represent more than half of the transgenic cultivars developed by multinational companies. EMBRAPA accounts for 30 of the 34 soybean cultivars protected by public institutions, totaling $88.24 \%$ of these protections. Besides, the private national company with the highest percentage of protections is COODETEC, with $7.22 \%$. Therefore, it is possible to conclude that the dominance of multinational companies in the protection of transgenic soybean cultivars is mainly ascribed to the activity of Monsanto in this market.

The same phenomenon occurs in cotton culture. In other words, all protected cultivars were developed by the private sector, and only one cultivar was produced by a national company, the Instituto Matogrossense do Algodão. All the others belong to a Monsanto affiliate, Delta \& Pine Land Technology Holding Company (Figures 1 and 2).

For the genotypes registered at MAPA, all the maize cultivars were developed by multinational companies and five companies alone own all the 448 cultivars (considering that the Agromen Tecnologia belongs to Dow AgroSciences). Therefore, about $80 \%$ of these genotypes belong to Syngenta (47.32\%) and Monsanto (31.47\%) (Figures 4 and 5).

Of the 293 registrations of transgenic soybean, $80.55 \%$ were produced by private companies; $40.96 \%$, by transnational companies; $39.59 \%$, by national companies, and $19.45 \%$, by public institutions. Monsanto (and its affiliates) are the most prominent, holding $25.26 \%$, COODETEC, $11.26 \%$ and EMBRAPA, $13.31 \%$ of the registrations of transgenic soybeans. Thus, higher competitiveness is observed in national companies for the number of registrations for this culture, but Monsanto remains the largest owner (Figures 4 and 5).

Seven registrations of cotton belong to a Monsanto affiliate (D\&PL). Bayer, Dow AgroSciences and the Instituto Matogrossense do Algodão have one cultivar each. Therefore, $90 \%$ of the GM cotton cultivars belong to three multinational companies (Figures 4 and 5).

It was also observed that, since 2006, the number of transgenic soybean cultivars is higher than the number of conventional cultivars. Besides this significant growth, the number of non-transgenic cultivars is decreasing, which demonstrates that conventional cultivars have been replaced by transgenic cultivars. Higher oscillation was observed in cotton for the number of GM cultivar protections, which presented higher numbers in 2007 and 2010 (Figure 3).

The relationship between the number of registrations of transgenic and non-transgenic cultivars corroborates the hypothesis that conventional seeds have been replaced. The first registrations of maize were carried out in 2008 and the number of transgenic and conventional cultivars was the same. In 2009 and 2010, the number of GM maize cultivars exceeded the number of conventional maize. The number of registrations of transgenic soybean cultivars has been higher since 2006 and increased over the years, while conventional crops have presented the opposite trend, and their number is decreasing. The number of GM cotton cultivars also surpassed the number of conventional cultivars in the last two years (Figure 6).

Besides, the rate of adoption of transgenic material by producers, which is estimated at $75.4 \%$ for soybean, $57.2 \%$ for maize and $26.7 \%$ for cotton in 2011 (Céleres, 2011), leads to a forecast of intense replacement of conventional crops by biotechnological crops for soybean, maize and cotton (the later at lower number). This situation is even worse that it appears, since, according to the Associação dos Produtores de Soja do Estado de Mato Grasso (Association 
of Soybean Producers of Mato Grosso - APROSOJA) and the Associação Brasileira de Produtores de Grãos Não Geneticamente Modificados (Association of Producers of Non-Modified Grains - ABRANGE), Monsanto is restricting the access of farmers to conventional soybean seeds (non-transgenic) by imposing percentages of sales for seed distributors, demanding that they sell $85 \%$ of "Roundup Ready" transgenic soybean seed and a maximum of $15 \%$ of nontransgenic soybean (Macedo, 2010).

This situation can be ascribed to the lobbying that multinational companies conduct, instead of the technological advantages of their seeds (Anonymous, 2010). It can be observed in the contracts that farmers are forced to sign, which have no basis in law. Thus, producers become vulnerable to contamination by third parties, application of herbicides on transgenic crops and consequent destruction of neighboring conventional crops, disregard for the norms on the labels, non-payment of awards for GMO-free production. Therefore, according to Pessanha and Wilkinson (2006) and Mechlem (2010), it is extremely difficult to maintain conventional crops in areas where genetically modified crops are cultivated. It leads farmers and society to increasingly depend on seeds patented by multinational companies, which will determine prices and control the world food market, since soybean and maize are essential for food production and are used in animal feed, plant oil and several industrial products. Together, these crops are responsible for about $80 \%$ of the grains produced in Brazil.

Besides, since the legislation does not establish a maximum price for royalties, and the market is controlled by few companies, producers are exposed to oligopolistic business strategies. They are almost obliged to pay the prices determined by the multinational companies.

Therefore, it can be concluded that the fast advance of biotechnology companies is worrying. The seed supply from these companies is almost a monopoly supported by law, leaving no choice for producers and leading to the fast replacement of conventional cultivars by transgenic cultivars, which are expensive and exclude small producers from the market, since seeds cannot be kept for later use. This situation concentrates production in the hands of a few large national agribusiness entrepreneurs.

\section{ACKNOWLEDGMENTS} (FAPERJ).

Research supported by Fundação de Amparo à Pesquisa do Estado do Rio de Janeiro

\section{REFERENCES}

Anonymous (2010). How to feed a hungry world. Nature 466: 531-532.

Araújo JC (2010). A Lei de Proteção de Cultivares: Análise de sua Formulação e Conteúdo. $1^{\mathrm{a}}$ ed. Edições Câmara, Brasília.

Brasil (1997). Lei 9.456. Institui a Lei de Proteção de Cultivares e dá Outras Providências. Available at: [http://www4. planalto.gov.br/legislacao/legislacao-1/leis-ordinarias/1997\#content]. Accessed January 15, 2011.

Brasil (2005). Lei 11.105/05. Estabelece Normas de Segurança e Mecanismos de Fiscalização de Atividades que Envolvam Organismos Geneticamente Modificados - OGM e Seus Derivados, Cria o Conselho Nacional de Biossegurança CNBS, Reestrutura a Comissão Técnica Nacional de Biossegurança - CTNBio, Dispõe sobre a Política Nacional de Biossegurança - PNB e dá Outras Providências. Available at: [http://www4.planalto.gov.br/legislacao/legislacao-1/ leis-ordinarias/2005\#content]. Accessed January 15, 2011.

Brookes G and Barfoot P (2010). GM Crops: Global Socio-Economic and Environmental Impacts 1996-2008, PG Economics Ltd., Dorchester.

Carvalho SIC, Bianchetti LB and Reifschneider FJB (2009). Registro e proteção de cultivares pelo setor público: a 
experiência do programa de melhoramento de Capsicum da Embrapa Hortaliças. Hort. Bras. 27: 135-138.

Céleres (2010). Relatório Sobre Biotecnologia: Primeiro Acompanhamento da Adoção da Biotecnologica no Brasil, Safra 2010/11. Available at: [http://www.comunique-se.com.br/deliverer_homolog/arq/cli/arq_1198_50255.pdf.]. Accessed January 13, 2011.

Céleres (2011). Relatório Sobre Biotecnologia: Segundo Acompanhamento da Adoção da Biotecnologica no Brasil, Safra 2010/11. Available at: [http://www.comunique-se.com.br/deliverer_homolog/arq/cli/arq_1198_61279.pdf]. Accessed January 23, 2011.

CONAB (2010). Companhia Nacional de Abastecimento. Levantamento de Safra: Grãos, Terceiro Levantamento, Dezembro 2010. Available at: [http://www.conab.gov.br/conteudos.php?a=1253\&t=]. Accessed January 23, 2011.

CTNBio (2011). Comissão Técnica Nacional de Biossegurança. Aprovações Comerciais. Available at: [http://www. ctnbio.gov.br]. Accessed January 18, 2011.

James C (2009). Global Status of Commercialized Biotech/GM Crops: 2009. ISAAA Brief n. 41. ISAAA: Ithaca.

Macedo D (2010). Agricultores Reclamam que Monsanto Restringe Acesso a Sementes de Soja Convencional. Available at: [http://www.gmwatch.org/index.php?option $=$ com_content\&view=article\&id=12237]. Accessed January 17, 2011.

Marinho CD, Martins FJO, Amaral SCS, Amaral Júnior AT, et al. (2011). Revisiting the Brazilian scenario of registry and protection of cultivars: An analysis of the period from 1998 to 2010, its dynamics and legal observations. Genet. Mol. Res. 10: 792-809.

Mechlem K (2010). Agricultural biotechnologies, transgenic crops and the poor: opportunities and challenges. Hum. Right Law Rev. 10: 749-764.

Munro A (2003). Monopolization and the regulation of genetically modified crops: an economic model. Environm. Dev. Econ. 8: 167-186.

Pessanha L and Wilkinson J (2006). Impactos Socio-Econômicos e Políticos da Expansão do Cultivo da Soja Transgênica Sobre os Agricultores na América Latina. In: VII Congresso Latinoamericano de Sociología Rural, Quito.

Potrykus I (2010). Regulation must be revolutionized. Nature 466: 561.

Teramoto JRS and Teixeira JV (2008). Propriedade Intelectual e Proteção de Cultivares. Série Tecnológica APTA. Manual Técnico DGE, Campinas.

Tollefson J (2010). The global farm. Nature 466: 554-556. 